\title{
Development of a Geospative Database of Land Plots for Assessment of Prospects for Development of Territories Using the Intellectual Analysis Methods
}

\author{
P. M. Demidova ${ }^{1, *}$, E. S. Korobitsyna ${ }^{1}$, A. M. Rybkina ${ }^{2}$ \\ ${ }^{1}$ Saint Petersburg Mining University, St. Petersburg, Russia \\ ${ }^{2}$ Emperor Alexander I St. Petersburg State Transport University, St. Petersburg, Russia \\ ${ }^{*}$ Corresponding author. Email: Demidova_PM@pers.spmi.ru
}

\begin{abstract}
The article is dedicated to the problems of assessing the prospects for development of territories on the example of suburban associations of citizens. Difficulties associated with the lack of the unified information resource that allow assessing and predicting possible changes associated with restriction of activities on land plots in connection with establishment of zones with special conditions for use of territories have been identified. The possibility of creating the specified resource by means of Quantum GIS using the methods of intellectual analysis is determined; the order of forming the system is formulated. Fragments of creation of a geospatial resource considering the prospects for development of territories, are clearly shown.
\end{abstract}

Keywords: cadastral registration, registration of rights, capital construction objects, zones with special conditions for use of territories, database, infrastructure, intellectual analysis.

\section{INTRODUCTION}

At present, national projects for development of infrastructure of territories are necessary to obtain the best results in the field of a high-tech economy, on the basis of which labor productivity increases, and, as a consequence, the standard of living of citizens increases [1].

Development of sustainable infrastructure ensures the social and economic well-being of the population [2]. However, presence of a developed infrastructure of the territory has the following duality: on the one hand, the investment attractiveness of developed territories increases, on the other hand, there are costs associated with both the costs of the direct creation of infrastructure, and with the emerging restrictions on use of lands that fall within the boundaries of the emerging zones with special conditions for the use of territories (ZSCUT) [1].

In the conditions of progressive urbanization, the population strives to satisfy the need for recreation, being closer to nature outside urban areas, but in addition, most industrial enterprises that imply establishment of ZSCUT relative to their own borders are located outside the city limits [3]. In this regard, the most expedient and visual is to assess the prospects for development of territories in relation to suburban associations of citizens [4].

Restrictions caused by presence of ZSCUT lead to inconveniences in implementation of economic activities, construction, and most importantly registration with state cadastral registration (GKU) and state registration of rights (GRP) to capital construction objects (OKS) located or planned for construction on land plots located or found to be within the ZSCUT.

At the moment, the Unified State Register of Real Estate (EGRN) does not contain information about a significant number of ZSCUT. In this regard, most of the inhabitants often simply do not have an idea about the existence of the ZSCUT in a particular territory, as well as about the restrictions provided for within the corresponding zone. You can clearly observe the problem of the lack of information about ZSCUT in the EGRN by the example of comparing the display of a part of St. Petersburg on a public cadastral map (Figure 1 a) [5], which reflects information about the zones entered in the EGRN with special conditions for use of territories, and on the map of the Regional Geographic Information System of St. Petersburg (Figure 1 b) [6], where information is entered on the basis of the results of the 


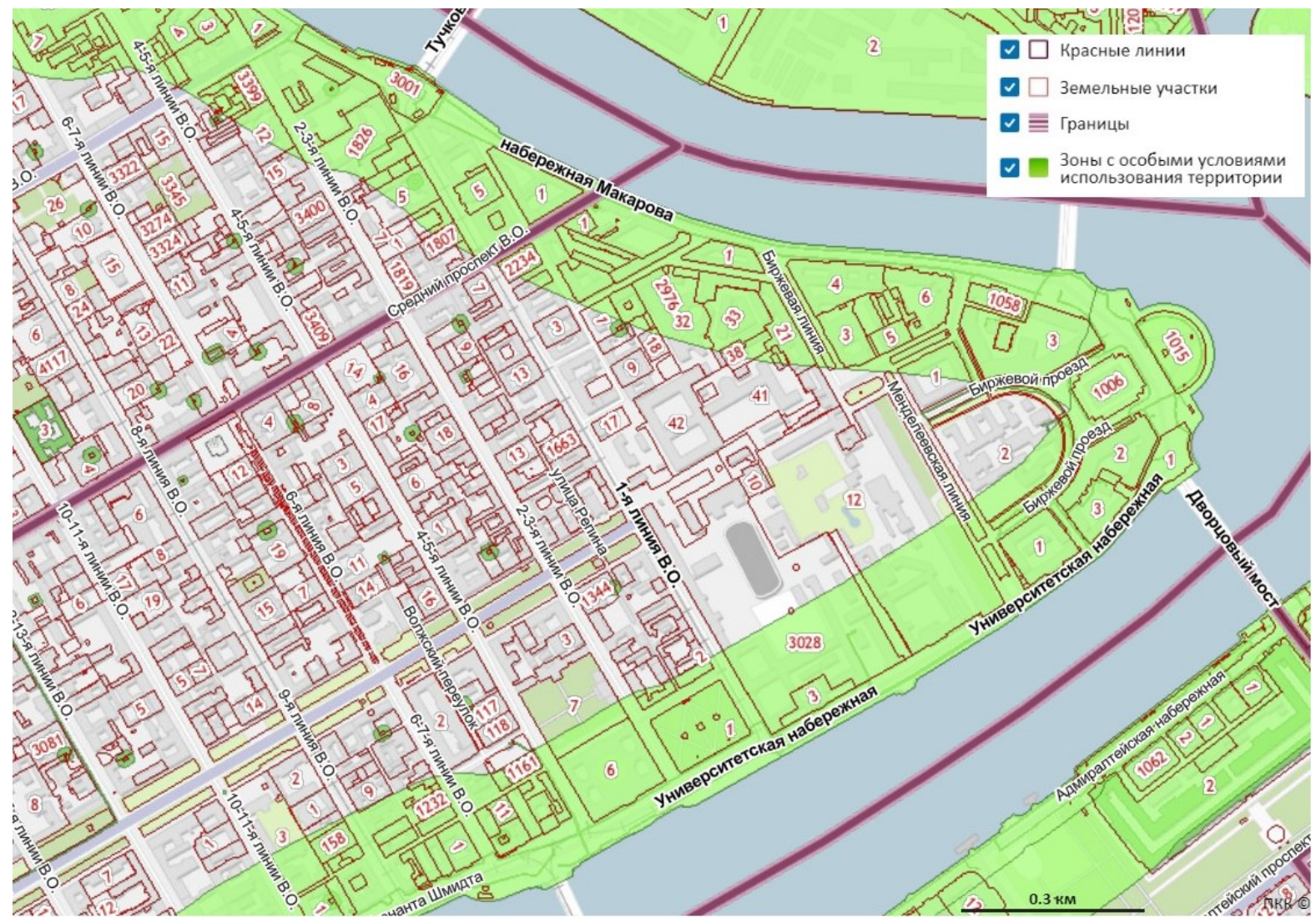

Figure 1 Zones with special conditions for use of territories in the territory of a part of Vasilievsky Island, displayed: a) on the Public Cadastral Map, Source: https://pkk.rosreestr.ru/, where: красные линии - red lines, земельные участки - land plots, границы - borders, Зоны с особыми условиями использования территории - Zones with special conditions for the use of the territory, Набережная Макарова - Makarov Embankment, Линии О.В. - O.V. Lines, Университетская набережная - Universitetskaya embankment, Биржевой проезд - Birzhevoy proezd, Адмиралтейская набережная - Admiralteyskaya embankment, Биржевая линия - Birzhevaya line, Менделеевская линия - Mendeleevskaya line, Дворцовый мост - Palace bridge.

control and executive survey transferred to the Committee of Property Relations of St. Petersburg.

In turn, the mandatory entry of information about the ZSCUT in the EGRN and within a limited time by the legal owners of the objects, in relation to which such zones shall be established, leads to violation, and often to the impossibility of conducting the offered economic and other activities by the rightholders of land plots within such plots.

Among other things, under the conditions of the "dacha amnesty" in the territory of the Russian Federation, during the construction of residential and garden houses, it is not required to obtain building permits, notifications of the start of construction, and, therefore, the requirements of the town planning regulations are not checked, which shall undoubtedly be considered when determining the development prospects of territories [7]. It shall also be noted that the main characteristic in the cadastral registration of buildings is the area, information about their height and volume is not considered, while the regulations for use of land within some ZSCUT have restrictions on the height of the OKS that fall within the boundaries of such zones. This problem can be solved by using building information modeling technologies, creating three-dimensional virtual models at different stages of the life cycle of objects, including for the purpose of monitoring their technical condition [8-11].

As a result, the governing bodies of specific municipalities actually do not have the resources to identify unauthorized buildings associated with violation of urban planning regulations, restrictions caused by presence of zones with special conditions for use of territories.

The main problem for owners and potential buyers of land plots is the lack of a publicly available information resource [12-14], reflecting the urban planning regulations of the territory, existing restrictions on the use of land, as well as having the ability to establish zones with special conditions for use of territories in the future. Forecast (prospective) maps and plans are mainly created in the environment of geographic information systems 


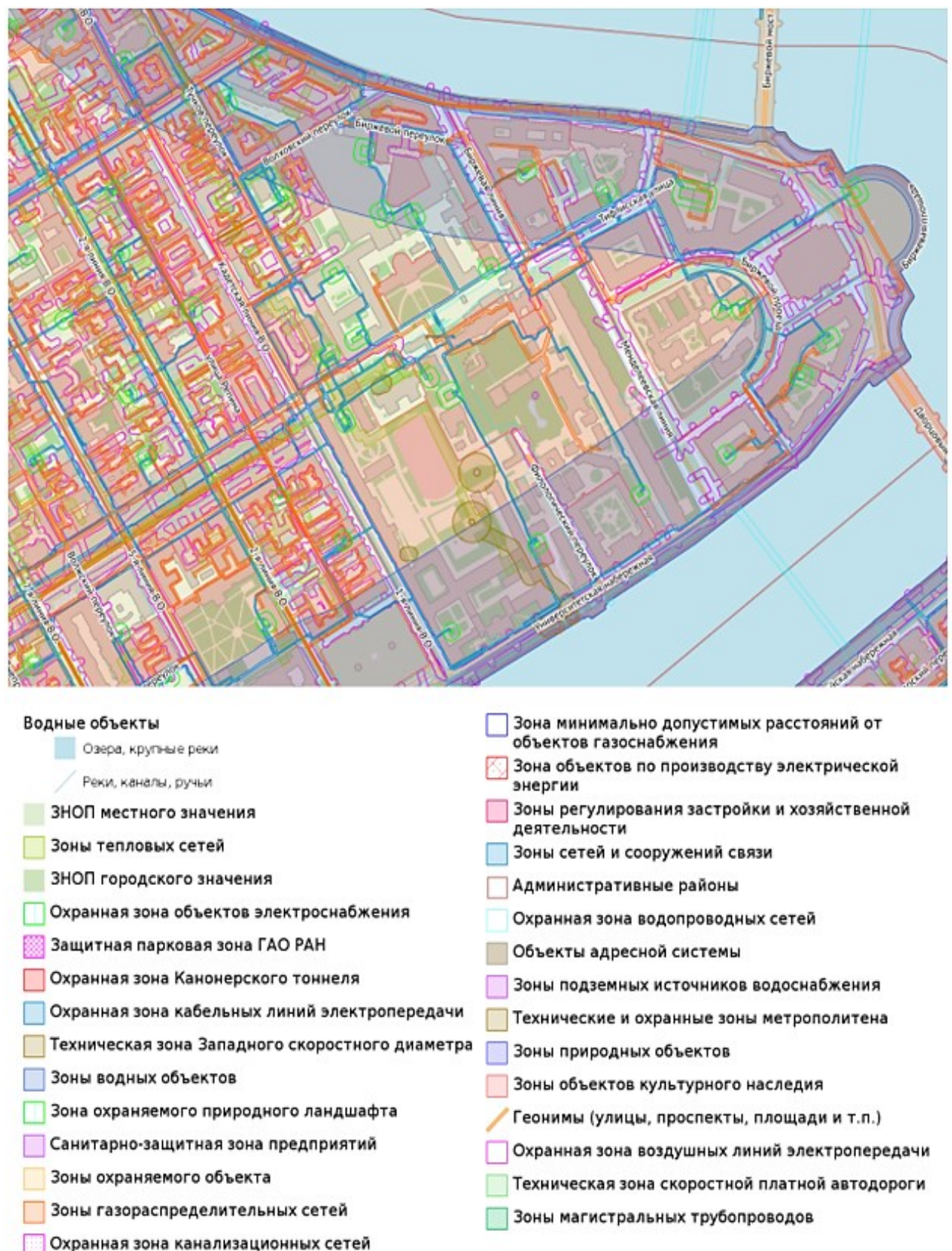

Figure 1. Zones with special conditions for use of territories in the territory of a part of Vasilievsky Island, displayed: b) on the RGIS Internet map, Source: https://rgis.spb.ru/mapui/ . where: Озера, крупные реки - Lakes, large rivers, Реки, каналы, ручьи - Rivers, canals, streams, ЗНОП местного значения - Green spaces of general use of local importance, ЗНОП тепловых сетей - Public green spaces of heating networks, ЗНОП городского значения - Public green spaces of urban importance, Охранная зона объектов электроснабжения - Protected zone of power supply facilities, Охранная зона Канонерского тоннеля - Security zone of the Kanonersky tunnel, Защитная парковая зона ГАО РАН - protective park zone of the State Astronomical Academy of the Russian Academy of Sciences, Охранная зона кабельных линий электропередачи - Security zone of cable power lines, Техническая зона Западного скоростного диаметра - Western High-Speed Diameter Technical Zone, Зоны водных объектов Water body zones, Зона охраняемого природного ландшафта - Protected natural landscape zone, Санитарнозащитная зона предприятий - Sanitary protection zone of enterprises, Зоны охраняемого объекта - Protected object zones, Зоны газораспределительных сетей - Gas distribution zones, Охранная зона канализационных сетей - Security zone of sewer networks, Зона минимально допустимых расстояний от объектов газоснабжения - The zone of minimum permissible distances from gas supply facilities, Зона объектов по производству электрической энергии - Power Generation Facilities Zone, Зоны регулирования застройки и хозяйственной деятельности - Zones of regulation of development and economic activity, Зоны сетей и сооружений связи - Zones of networks and communication facilities, Административные районы - Administrative regions, Охранная зона водопроводных сетей - Protected zone of water supply networks, Объекты адресной системы - Address system 
objects, Зоны подземных источников водоснабжения - Underground water supply zones, Технические и охранные зоны метрополитена - Technical and security zones of the metro, Зоны природных объектов - Natural object zones, Зоны объектов культурного наследия - Cultural heritage sites, Геонимы (улицы, проспекты, площади и т.п.) - Geonyms (streets, avenues, squares, etc.), Охранная зона воздушных линий электропередачи - Protected zone of overhead power lines, Техническая зона скоростной платной автодороги - High-speed toll road technical zone, Зоны магистральных трубопроводов - Main pipelines zones.

and successful functioning of the infrastructure is the primary goal of the GIS application [17-20].

\section{MATERIALS AND METHODS}

The open public geographic information system Quantum GIS (QGIS), having the ability to work with various ready-made map substrates, through a layer-bylayer model of data organization, allows solving a huge range of various functional tasks [21] necessary to create an information resource that helps assess the development prospects of territories [22].

By means of QGIS, on the example of the territory of the dacha non-profit partnership Zateylivoye of the Leningrad Region, a geospatial database of land plots is created on the basis of cadastral plans of the territory of the quarters in which the dacha partnership is located, as well as other EGRN information.

The database includes information directly about the land plots of the dacha partnership itself, capital construction projects registered in the cadastral register, zones with special conditions for use of territories, information about which is entered in the EGRN, territorial zones of both the most suburban non-profit partnership Zateylivoye, and adjacent territories.

By analyzing the location of the dacha partnership land plots and the types of their permitted use, within each plot, using the wide functionality of QGIS, zones are formed that reflect the urban planning regulations of the territory.

Built-up land plots are determined using QGIS vector analysis tools; parts of land plots encumbered with various ZSCUTs or completely free from restrictions on use; areas of parts of land plots on which, considering the restrictions, it is allowed to place the OKS.

\section{RESULTS AND DISCUSSION}

Based on the study of the types of territorial zones bordering the dacha partnership Zateylivoye, using proximity analysis tools, the presence of a territorial zone that looks like a "special purpose zone" consumption, etc. is determined; it is requiring the establishment of sanitary protection zones with a width of up to 500 meters relative to their own boundaries, within the boundaries of which the construction of residential and garden houses is completely prohibited. In this connection, the idea of forming a buffer zone relative to the boundaries of the suburban non-commercial partnership Zateylivoye, 500 meters wide, within which the Administration of the relevant municipality will restrict the issuance of land plots for certain types of permitted use, in order to avoid situations of imposing a sanitary protection zone prohibiting construction within their borders, on land plots intended for placement of residential and garden houses arises and is implemented (Figure 2). Such a buffer zone will allow the owners of land plots of the dacha partnership not to face the problems of cadastral registration and registration of rights to the OKS built within the boundaries of their own land plots, and potential buyers of land in the territory of Zateylivoye partnership - to be calm about the full use of the plots they prefer to purchase.

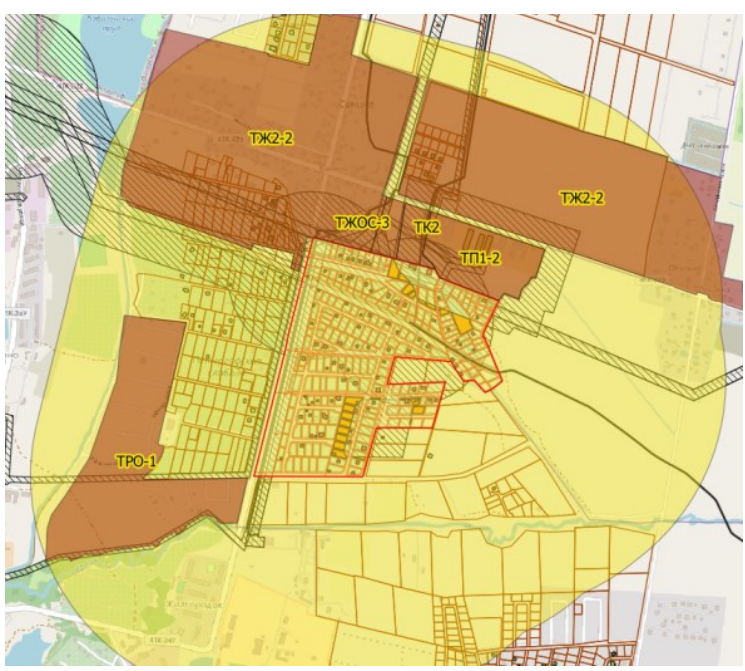

Figure 2 Buffer zone of the dacha non-profit partnership Zateylivoye.

For the Administration of the municipality, it is important to notice and eliminate unauthorized buildings associated with violation of both urban planning regulations and the procedure for using land within the boundaries of the ZSCUT. Through use of tools for analyzing vector objects by spatial position, capital construction objects were identified, the coordinates of the characteristic points of the contour are contained in the EGRN, erected contrary to the requirements of the current legislation, their share is more than $30 \%$ of the total number of OKS in the territory of the dacha partnership, in Figure 3 such objects highlighted in yellow. 


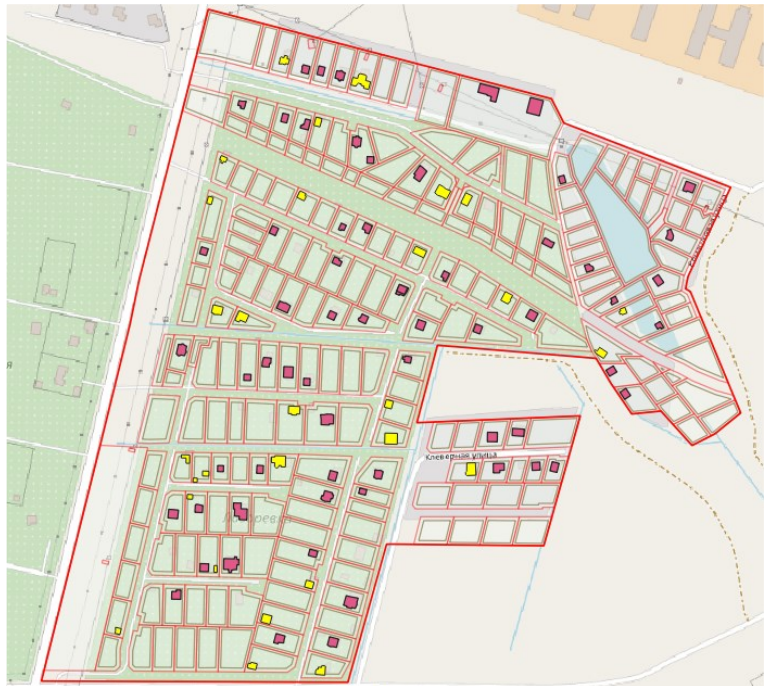

Figure 3 Capital construction objects erected in violation of the current legislation requirements

Using tools for analyzing the spatial position of objects and tools for analyzing the proximity of objects, it is revealed the presence in the immediate vicinity of the boundaries of a dacha non-commercial partnership of a manufacturing enterprise of IV hazard class, which has a sanitary protection zone of 100 meters, within the boundaries of which any development is prohibited [23, $24,25]$. Based on the information revealed, it seems possible to determine both the spatial position of a part of the land plot, construction on which is permissible, and the numerical value of the area of that very part. Such information will help land owners in placement of a future residential or garden house, and potential land buyers - in planning to purchase a land plot. Parts of land plots that allow the construction of residential and garden houses, considering the requirements of urban planning regulations, as well as the restrictions established by the sanitary protection zone of an enterprise of IV hazard class, are highlighted in blue in Figure 4.

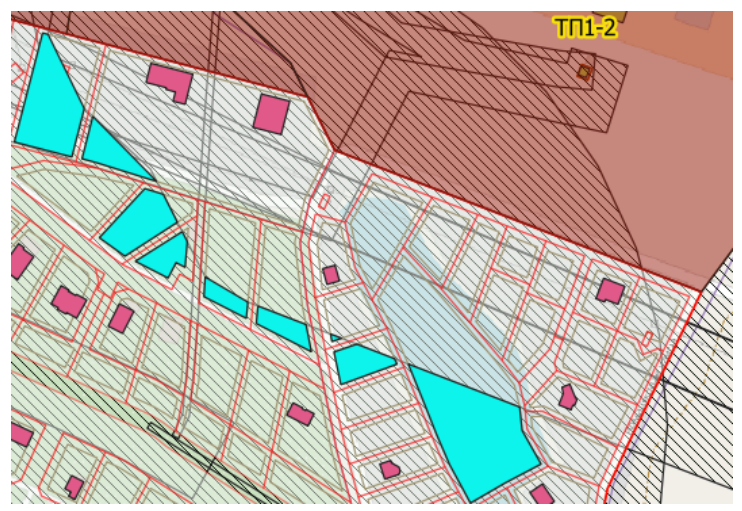

Figure 4 Parts of land plots that allow the OKS construction

In addition, if there is information about the number of floors of capital construction projects, the Administration of the municipality will be able to easily monitor compliance with the requirements of the legislation in the field of urban planning regarding the maximum number of aboveground floors of residential and garden houses, as well as compliance with the requirements for restrictions on the height of buildings being erected, established by specific ZSCUT (Figure 5).

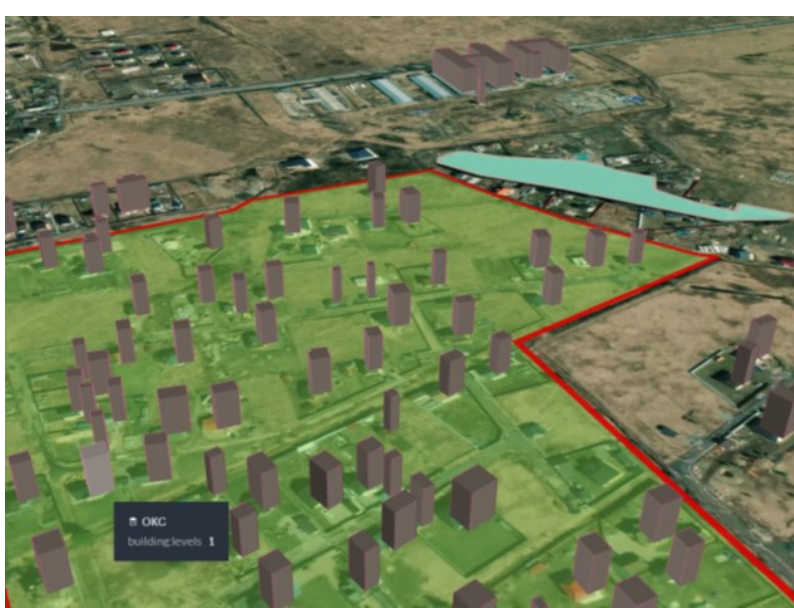

Figure 5 Three-dimensional visualization of capital construction objects of the suburban non-profit partnership Zateylivoye.

Source: https://kepler.gl [26].

\section{CONCLUSION}

As a result of the works carried out, the need for implementation of a geospatial database of land plots considering the urban planning regulations, as well as zones with special conditions for use of territories, in all regions of the Russian Federation was proved. The geospatial database, created using analysis tools using QGIS means, allows you to solve the following issues in the field of assessing the prospects for development of territories:

- first of all, the Administration of the municipality will be able to identify capital construction objects built in violation of the city planning regulations, as well as restrictions caused by specific ZSCUT;

- due to presence of a special buffer zone relative to the borders of suburban associations of citizens, the Administration of the municipality has the ability to more thoroughly control the issue of land plots for various types of permitted use, as a result, the problem of the impossibility of making the state cadastral registration and registration of rights to OKS erected within the ZSCUT is prevented, information about which was entered in the EGRN after the acquisition of the land plot;

- availability of information about territorial zones in the geospatial base of land plots allows "to establish ZSCUT for the future" by analyzing the types of territorial zones, types of permitted use of land plots and analysis of their proximity to the offered residential development; 
- moreover, existence of the specified database of land plots allows owners and potential buyers of land to determine the area, configuration and position of parts of land plots on which a residential or garden house can be located.

Among other things, the need to create such a database in three-dimensional space was determined, this will allow the Administration of the municipality to monitor compliance with the requirements for the height of capital construction objects.

\section{REFERENCES}

[1] E. N. Bykova, Assessment of negative infrastructural externalities when determining the land value. In: Journal of Mining Institute, 247 (2021) pp. 154-170. DOI: https://doi.org/10.31897/PMI.2021.1.16.

[2] I. Dyachkova, M. Skachkova, V. Kovyazin, The influence of transport vibrations on the condition of Russian cultural heritage objects. In: IOP Conference Series: Materials Science and Engineeringthis link is disabled, 817(1) (2020) 012009. DOI: https://doi.org/10.1088/1757899X/817/1/012009.

[3] M. V. Volkodaeva, O. A. Taranina, Y. A. Volodina, V. A. Kuznetsov, Development of industrial environmental control methods. In: IOP Conference Series: Earth and Environmental Science, 378 (2019) pp. $1-5 . \quad$ DOI: https://iopscience.iop.org/article/10.1088/17551315/378/1/012108/pdf.

[4] E. N. Bykowa, A. A. Bogolyubova, D. D. Simonova, Analysis of the water bodies zones influence on the cadastral value of garden and horticultural land plots. In: IOP Conference Series: Earth and Environmental Sciencethis link is disabled, 350(1) (2019) 012069. DOI: https://doi.org/10.1088/17551315/350/1/012069

[5] Public cadastral https://pkk.rosreestr.ru/\#/search.

map.

[6] Internet map of the Regional Geographic Information System of St. Petersburg. https://rgis.spb.ru/mapui/.

[7] A. N. Asaul, M. A. Asaul, P. B. Liulin, N. V. Chepachenko, Housing Construction in Russia: Trends and Medium-Range Forecasts. In: Studies on Russian Economic Development, 30 (3) (2019) pp. 313-318. https://doi.org/10.1134/S1075700719030055.

[8] M. E. Skachkova, O. J. Lepikhina, V. V. Ignatova, Information support of monitoring of technical condition of buildings in construction risk area. In: Journal of Physics: Conference Series, 1015 (2018) pp. 42056-42056.

DOI: http://iopscience.iop.org/article/10.1088/17426596/1015/4/042056/pdf.

[9] L.A. Goldobina, P.A. Demenkov, V.L. Trushko, The implementation of building information modeling technologies in the training of bachelors and masters at Saint Petersburg Mining University ARPN. In: Journal of Engineering and Applied Sciences, 15 (2020) pp. 803-813. DOI: http://www.arpnjournals.org/jeas/research_papers/r p_2020/jeas_0320_8163.pdf.

[10] T. Maleeva, L. Selyutina, N. Frolova, Use of modern technology of information modeling in capital construction object life cycle management. In: IOP Conference Series: Materials Science and Engineering, 687 (4) (2019) 044002. DOI: https://doi.org/10.1088/1757-899X/687/4/044002.

[11] O.M. Lenkovets, Housing renovation in Russia and engineering and environmental aspects of renovation programs. In: Journal of Advanced Research in Dynamical and Control Systems, 12 (2020) pp. 1060-1068.

DOI: https://www.jardcs.org/abstract.php?id=3520.

[12] N. Vasilenko, M. Khaikin, A. Lapinskas, Ways of achieving the institutional equilibrium in the context of an emerging single digital space. Studies in Computational Intelligencethis link is disabled, 826 (2019) pp. 559-567. DOI: https://doi.org/10.1007/978-3-030-13397-9_61.

[13] N. Masyuk, M. Bushueva, Z. Bragina, The Institutional Regulatory Environment of the Digital Ecosystem: Theoretical Approach and Russian Experience. In: SHS Web of Conferences, 73 (2020) 01019 .

DOI: https://doi.org/10.1051/shsconf/202073010.

[14] K. Reizenbuk, T. Sarapulova, S. Shchedrin, I. Shchedrina, Application of distributed computing in developing architecture of intelligent information system for automated stock exchange trading. In: Journal of Advanced Research in Dynamical and Control Systemsthis link is disabled, 11(8 Special Issue) (2020) pp. 2549-2555. DOI: https://www.jardcs.org/abstract.php?id=3004.

[15] A. Osipov, V. Dmitriev, V. Kovyazin, A. Romanchikov, Cartographo-Mathematical Modelling of Landscape Diversity for Land Use Planning Purposes. In: IOP Conference Series: Earth and Environmental Science, 574(1) (2020) pp. 1-7, 012058. DOI: https://iopscience.iop.org/article/10.1088/17551315/574/1/012058.

[16] V. Kiselev, N. Guseva, A. Kuranov, Creating Forecast Maps of the Spatial Distribution of Dangerous Geodynamic Phenomena Based on the Principal Component Method. In: IOP Conference 
Series: Earth and Environmental Sciencethis link is disabled, 666(3) (2021) 032071. DOI: https://doi.org/10.1088/1755-1315/666/3/032071.

[17] T.I. Baltyzhakova, E.S. Bryzhataya, Analysis of urban territory in terms of accessibility to social objects. In: Journal of Physics: Conference Seriesthis link is disabled, 1333(3) (2019) 032005. DOI: https://doi.org/10.1088/1742-6596/1333/3/032005.

[18] M. A. Pashkevich, T. A. Petrova, Assessment of widespread air pollution in the megacity using geographic information systems. In: Journal of Mining Institute, 228 (2017) p. 738. DOI: https://doi.org/10.25515/pmi.2017.6.738.

[19] N.V. Kanashin, Experience of modern programs and geographic information systems application at formation of land parcels for constructing linear structures. In: Geodezia i Kartografia, 80 (6) (2019) pp. 48-53. DOI: https://doi.org/10.22389/00167126-2019-948-6-48-53.

[20] E. Pesotskaya, L. Selyutina, L. Egorova, Actual aspects of modeling method application in organization of construction management . In: IOP Conference Series: Materials Science and Engineering, 687 (4) (2019) 044005. DOI: https://doi.org/10.1088/1757-899X/687/4/044005.

[21] N.S. Kopylova, M.G. Mustafin, M.E. Mishina, The functionality analysis of the quantum GIS Geoinformation system as a part of the small-scale maps creation. In: IOP Conference Series: Materials Science and Engineeringthis link is disabled, 698(4) (2019) 044016. DOI: https://doi.org/10.1088/1757899X/698/4/044016.

[22] N.N. Masyuk, M.A. Bushueva, L.K. Vasyukova, A.E. Kiryanov, Platforms of digital experience and digital transformation in an innovative economy. In: SHS Web of Conferences, 73 (2020) 01019. DOI: https://doi.org/10.1051/shsconf/20207301019.

[23] D. Patokin, A. Danilov, A. Isakov, Environmental monitoring of natural waters in the zone of impact of an enterprise producing explosives. In: IOP Conference Series: Earth and Environmental Sciencethis link is disabled, 578(1) (2020) 012038. DOI: $\quad$ https://doi.org/10.1088/17551315/578/1/012038.

[24] I.V. Potseshkovskaya, A.N. Soroka, Revitalization of urban industrial areas based on sustainable development principles. In: E3S Web of Conferencesthis link is disabled, 266 (2021) 08012. DOI: https://doi.org/10.1051/e3sconf/202126608012.

[25] Mariya A. Pashkevich, J. Bech, V. A. Matveeva, A. V. Alekseenko, Biogeochemical assessment of soils and plants in industrial, residential and recreational areas of Saint Petersburg. In: Journal of Mining Institute, 241 (2020) pp. 125-130. DOI: http://dx.doi.org/10.31897/PMI.2020.1.125.

[26] The powerful open source geospatial analysis tool for large-scale data sets. https://kepler.gl/. 